\title{
Mabinogion
}

\section{Josef Baudis}

To cite this article: Josef Baudis (1916) Mabinogion, Folklore, 27:1, 31-68, DOI:

10.1080/0015587X.1916.9718909

To link to this article: http://dx.doi.org/10.1080/0015587X.1916.9718909

曲 Published online: 01 Feb 2012.

Submit your article to this journal 주다

Џll Article views: 3

Q View related articles $₫$ 


\title{
MABINOGION.
}

\author{
BY JOSE BAODIS.
}

Ir has long been recognised that the Mabinogion is a storehouse of old motives, but very little has been done in the way of tracing these particular motives to the methods adopted by the Welsh story-tellers in their arrangement of them. This paper is intended as a contribution to this inquiry.

PLAN OF THE INQUIRY.

Part I.: The First branch or the Mabinogion.

A. Pryll and Arawn: Three motives: (a) Exchange of external appearance.-Norse parallels.-Explanation of the belief.-(b) Chaste cohabitation.-Parallels in Norse and the Twin Brothers Tale.-(c) Killing of Havgan.

B. The Other IVorld: Pwyll's journey belongs to the Other World expeditions. Irish parallels,-Mr. M'Culloch's theory about the Celtic Elysium.-Are we to presuppose two different ideas : that of Elysium and that of the Land of the Dead? Irish side and ancestral cult. Side denotes Irish supernatural beings. Triatha De Danann belonged originally only to the side of the Connaught cycle. Abodes of side convey both ideas: that of Elysium and that of the Country of the Dead. In Welsh we find these two different aspects of the Other World, and similarly in other folklore. We confine ourselves to the Other World. The double aspect of the Other World is to be explained through the development of primitive belief. Connection of the insular Celtic belief with the Gaulish religion. The 
King of Other World is represented as Death the Hunter. Pwyll's relation to the Other World.

C. The Rest of the First Branch. Motives: Pwyll and Gwawl is an independent Mäkrcken.-Rhiannon.-Parallels to this story.-Kidnapping of Pryderi belongs to the Mysterious Hand motives.-Plight of Rhiannon and the Abandoned Wife story (and Female Taboo Breaker).Traces of Supernatural Birth (two categories of such Birth stories).-Irish Birth stories.-How the fusion of all these motives came to pass ?-Abandoned Wife motive was introduced to account either for some aspect of Rhiannon's character or it was to explain Pryderi's name, which was explained as derived from pryder. Etymology of the name. Pryderi's relation to Annwin and to the Gaulish tradition about the origin of the Gaulish nation.

D. Gwri Wallt Euryn and Mabon vap Modron. Gwri is probably not identical with Mabon, because the history of Gwti (Pryderi) and that of Mabon are not identical.-If everything told about Pryderi relates to Gwri, how came Pryderi into the Mabinogion at all ?-The similarities of different tales are to be explained in the way that in Wales there existed similar tales about different persons.

E. The Origins of the Mabingi Tales. Mr. W. J. Gruffydd's theory. We have no proofs that the first branch of the Mabinogion is of the same origin as the Irish saga of Mongan. The history of Llew Llawgyffes is not identical with.the Irish Aided Conroi.-Possibility of foreign influences,-There are striking similarities between the Welsh story and the Egyptian tale.-The Irish story of Etáin and a Jataka story.

Pát I.: The first Brancil of tite Mabinogi. A. Pryll and Arawn.

(a) The first motive, the mutual exchange of external appearance, forms a leading motive in the northern version of : the. Nibelungen-cycle (Norse Niflung). First, it. 
occurs in the introduction to the whole cycle, and then later when Sigfrid (Siguror) wins Brunhild (Sigrdrffa) for Gunther (Gunnar). The idea of mutual exchange of the body is based on the conception of the body being similar to removable clothes (Icel. hamr, "skin"; cf. hamramer or eigieinhamr, "able to exchange one's form"); a witch or magician can change the appearance of another man by putting the hamr on him, and it is the task of the hero to destroy this magical hamr. The swanmaidens cannot resume their bird-shape if their hamr is stolen from them. This belief is based on primitive conceptions of life. To primitive man there is no difference between an animal and a human being; their external form is only a casual accident: " the bear whom the savage meets in the woods is too cunning to appear and to battle with him as a man, but he could if he chose" (Hartland, The Science of Fairy Tales, 26). Our motive is only a logical consequence of this ancient savage belief: if shape-shifting is possible, why cannot two human beings also exchange their shape one with another? This motive is also very closely connected with the True Wife motive: the wife is changed into an animal and the sorceress or her daughter takes her place. In most of these stories the impostress maintains her position by disguise; in some stories the quid pro quo can be explained by the social conditions of the indigenous culture (cf. M'Culloch, Childhood of Fiction, pp. $24 \mathrm{fi}$.), but some at least must belong to our group, so eg. the Bushman story, "The Wife of the Dawn's Heart Star" (Bleck \& Lloyd, Bushman Folklore, pp. 89 ff.), where a hyena takes the place of $K \delta$-ginyif-tara, the wife of Jupiter star. But is this belief commensurate with the belief that the soul retains the characteristics of the body (man's double)? To this we can answer that it is not necessary that those ideas should coincide; we find maniy such discrepancies which may be due to different culturestrata. As regards the different conceptions concerning 
the soul and body, we have the best example in the old Egyptian creed. However it may be, the shape-shifting theory does not presuppose that the person is totally transformed; Norse belief makes the integral part of the original personality, the eyes, to persist, while all the rest is changed. ${ }^{2}$ It is difficult to say whether there was anything similar in Welsh. At any rate we have no traces of it. It is, of course, not necessary to assume any historical continuity between the Welsh and Teutonic motives. It is, however, remarkable that in both Teutonic and Welsh we find this motive combined with that of chaste combitation.

(b) This last motive we find very often in the story of the Twin brothers (vide Hartland, The Legend of Perseus, i. pp. 24 ff.). The first brother, who has won the hand of a princess, is turned to stone; his twin brother, learning of his brother's peril, comes to his court, plays his role. (at night he sometimes puts his sword between himself and his sister-in-law), and finally disenchants the petrified hero. This story is known as a modern folk motive through the whole of Europe. But here the resemblance between the two brothers accounts for the situation.

(c) As to the third motive, we often find that a magician or spirit can be killed only in some particular way, i.e. there are certain taboos limiting his life-powers. In the theme we are studying the taboo is that the hero shall not give his adversary a second stroke. In modern Irish stories we find another motive: the giant's head after it has been hewn off creeps to the body again, and the hero prevents its reunion with the body; for if the head should

1The Irish lay stress on the preservation of the human voice: "Agus do ghabh aithreachas ann in toife, agus adubhairt: ' $\delta$ nach feadaim aon chabhair eile do thabhairt orraibh feasda biaidh bhur n-firlabhra fein agaibh ... agus biaidh bhúr dtreoir agus bhúr n-oirbheart agaibh." Oidhe Chloinne Lir, 820.

'Miss Weston wrongly compares with this motive Peredur's sword (Parcival, L I47). 
be joined to the body, not even the fairy doctors could sever it from the body again.

\section{B. Other World.}

This first part of the first Branch had originally to account for Pwyll's connection with Annwvn. This association of Pwyll with Annwvn is mentioned also in the fourth Branch of Mabinogi (Math vab Mathonwy), where Pwyll gets pigs as a present from the Other World (B.B. fo. 752, W.B. 191 : Moch y gelwir weithon. "Pwy biewynt wy?" Pryderi vab Preyll, yd anvonet idaw o Annwn, y gan Arawn vrenhin Annwen).

Pwyll's voyage to Annwvn belongs to the category of Other-World voyages (Ir. eachtra). These voyages are often of a friendly character, but sometimes they take the form of a conquest of the Other World. Help given by mortals to the King of the Other World is a frequent motive ${ }^{2}$ in the Irish saga literature that of Cúchulainn (in Serglige Conculaind) is the most typical. Cúchulainn helps Labraid Luath Lim ar clrideb, the King of Mag Mell, against his enemies, who belong also to the inhabitants of the Other World. In modern Irish folk-tales we find a similar motive: a mortal man is requested by the stdheogai to help them in their match against other stdinedgai, or he is to assist them in kidnapping the King of France's daughter.

From these later parallels we may argue that there was a belief that a human being is able to vanquish the fairy people, etc., and this doctrine may be the real reason why Arawn requests Pwyll to fight for him against Havgan.

Now, there might be another question: are the Irish sidheogai identical with the inhabitants of Annwwn, and what is Annwvn? There are scholars who accept two Other Worlds, i.s. "the Land of the Dead" and

-CF. A. C. L. Brown, Hanvard University Stmdies and Noles in Lilmature and Philalogy, vili. 41. 
Elysium. Mr. M'Culloch (The Religion of Ane. Celts, p. 370) is of the opinion that "the origin of the Celtic Elysium belief may be found in several myths of a golden age long ago in some distant Elysian region, where men had lived with the gods. Into that region brave mortals might still penetrate... Possibly the Celtic myth of man's early intercourse with the gods in a lost region took two forms. In one it was a joyful subterranean region whither the Celt hoped to go after death. In the other it was not recoverable, nor was it a land of the dead. The Celtic Elysium belief... is always of this second kind. We surmise, however, that the land of the dead was a joyous underworld ruled over by a god of fertility and of the dead, and from that region men had originally come forth. The later association of gods with the sid was a continuation of this belief, but now the std are certainly not a land of the dead, but Elysium pure and simple. There must therefore have been at an early period a tendency to distinguish between the happy region of the dead and the distant Elysium, if the two were ever really connected."

This theory, however, does not account for all the tales which refer to the Other World, because there are stories where the inhabitants of the Other World are by no means friendly to the intruders into their domains. Again, it has to be proved whether the Irish side do not owe their origin to ancestor-worship; and finally, the above-quoted theory presupposes that the old Celtic cultus was in olden times so developed and uniform that there was no room for contradictory ideas as regards the posthumous existence of man and more general conceptions of the universe.

Now, ancestor-worship has not been taken enough into account in the study of Celtic mythology, and yet we must take into consideration the fact that some of the fairy hills (sid) are really old burying places, eg. the Brugh of Boyne is the abode of Oengus (Mac ind-Oc). According to Maelmuire Othna, the nobles of the Túatha Dé Danann 
were buried in a Brugh (so Dagda with his three sons and Ollam and Ogma). According to Acallam na Senórach, three sons of Lugaid Menn came to the Brugh of Boyne and fasted; Bodb Derg (Dagda's son) came out of the Brugh and said: "It was revealed to the Tuatha De Danann that ye would come to fast here to-night for lands and great fortune." They went into the Brugh, and remained there for three days. Another old burial place, Cruachan, is the abode of the Stde of Connaught. This proves that the stde are really connected with the old burial places. Now these side are identical-as we have already seen-with the chiefs of the Túatha Dé Danann. We find the same in the old Irish sages; so Lug mac Ethlenn says to Cúchulinn (Tdin bo Cuailnge, ed. Strachan, 11. 1805-6): Is messe do athair a sstdib. The composer of Fiacc's Hymn uses the word stde to denote the pagan gods (v. 4r): For twaith h-Erenn bai temel tuatha adortais stde. One might, however, suppose that this identification of stde is later, and that originally the Tuatha De Danann were a race of gods. But what we know about the Tiatha De Danann conveys a rather different idea; they were superhuman beings whose power was due to their knowledge of magic, and they differ very little from powerful magicians. It is, at least for me, a question whether the insular Celts had any idea of gods in the same sense as the Greeks and Romans. Neither does the name of Tuatha De Danann suggest that the bearers of this name were real gods. According to the Lebor Gabala, the Tratha DE Danann preceded the Milesians, who deprived them of the possession of the land. Now, some Irish tribes only are of true Milesian origin, others derive their origin from the Tratha DE Danann, and others again from the Fir Bolg.

1Cf. Cath Maige Tuired Cunga, \&20. "Imthusa Tuaithe De Danann (N.B. singular number), roforbredur co clos a scela fa (th)ixib in talman. Robl dia draidjechte ecu fen Eochsid Ollathir in in Dagda mor, wair be daigdia $t$. Robadur ta(isig) trena talchara acu 7 fir caineladnacha gachn ceirde." 
We find in Irish genealogies occasional names of the Tratha De Danann. We might explain these facts simply as arising out of the euhemeristic tendencies of the Irish genealogists, according to which the Christian historians endeavoured to change the old Irish nature gods into old kings; but such a tendency must have been supported somehow by the old tradition, for instance by the occurrence of the Tuatha DE Danann in the old pedigrees, or by a tradition according to which the old gods lived on the earth. Such traditions are by no means rare in the mythical history of nations. And, further, we must not forget that there were different strata of population in ancient Ireland, as e.g. Fir Bolg, Ulstermen, Picts and Milesians, and so it would be most natural to regard the Tratha De Danann as such a tribe, especially since some races derived their origin from them.

The name Tratha DE Danann probably belonged only to some of these stde, and was extended by the Lebor Gabala to all such beings. It was the same case as with the Fir Bolg: the territory of Bolg is proved by L.U. 56 /T.B.C. 1.87 to have been somewhere near Roscommon, as L.L. 56" has instead of Bolga: Badbgna. This Bolga (acc. plur.) was thus a name of local character, and Lebor Gaballa has changed it to the name of a whole race. Now the cycle in which Túatha DE Danans play a really important role is the cycle represented by Cath Maighe Tuireadh and similar stories, and even this Cath Maighe Tuiread is localised in Connaught, and the memory of this battle survives there to our own day. (I have heard it as cath na bpunnann) Take now the Ulster saga. What have the Tuatha DE Danann to do there? There were obviously no traditions of such a character. Here the supernatural characters appear only as side. The same holds true for the $\bar{E}$ rnai cycle (Conaire Mor). Here the side have a prominent role, and their supernatural character is here quite clear, but there is no sign that there 
ever existed in the Érnai district a saga about Tratha De Danann, a divine race, conquerors of the Fomorians and predecessors of the Milesians, and so it appears that side is an original old Irish name for supernatural beings. The name Túatha Dé Danann was known only in some parts of Ireland (Connaught), and Lebor Gaballa, employing this name for its purposes, made it known through the whole of Ireland. And so we see that our attention must be turned only to the side.

We understand now quite well why the composer of Fiacc's Hymn wrote

tuatha adortais side.

Most of them were dei terreni, but this does not exclude (at least in so me degree) ancestral character. In later times they are equivalent to fairies, and these are, e.g. in Slavonic, to a great extent "souls" of deceased maidens. This parallel would also account (at least partly) for the Irish Tir na mban. One might object to this explanation that std is always a fairyland, a pleasant place, where there is no sorrow, and it is a privilege of some people only to come there. But this fairyland seems by no means to be always such a desirable country. In modern folklore the kidnappings of human beings by fairies are considered as something rather unpleasant. The Old Irish Echtra Nerai does not represent the inhabitants of Cruachan-Sid as very benevolent to the Connaught people. The same we might gather from the story of Etán.

We must not forget, further, that for primitive man there was no precise break between death and life. The dead lived in the tomb (or in the Other World) the same life as he lived in this world, and it was not believed impossible that the dead could revive again.

After all, we must not forget that this same fairyland is sometimes the object of expeditions which resemble closely expeditions to Hades. So, for example, the expedition to 
the Isle of Falga, where the Irish people get the wonderful cauldron. We find a similar expedition mentioned in a Welsh poem (Skene, ii. 181, Book of Taliesin, 256), where this cauldron is called peir pen annweyn, and we learn that Arthur made a disastrous expedition to this region ( $A$. phan aetham ni gan Arthur... namyn scith ny dyrreith o Gaer Vedwit). The Caer Sidi mentioned in the same poem is a horrible prison of Gweir, who sits there before spoils of Hades (rac preideu annweryn), and yet the same place appears in another poem like paradise (Skene, ii. 155, B. of Tal. 16):

\section{Ys kyweir vyg kadeir yg Kaer Sidi, Nys plawd neb heint a heneint a vo yndi. Is guyyr Manawyt a Phryderi. Teir oryan y am tan a gan recdi. Ac am y banneu ffrydyeu gzoeilgi. Ar ffynnhawn frreythlawn yssydd o duchti. Ys chroegach nor guin gwyn y llyn yndi.}

All these facts prove only that Annwvn and fairyland have two aspects: one of a beautiful blessed country and the other of a dangerous region. This other aspect is not infrequent in folklore; Teutonic and Slavonic folklore knows many stories dealing with expeditions to that country; the Old Babylonian has a story about Izdubar's expedition to Hades (Archiv für Religionswissenschaft, xii. 275 f.), and the Kichés of Central America believed that Hun-Ahpu and Xbalanque came to the realms of Xibalba (Underworld) [Popol Vuh, bk. ii.].

And so, I think, it is safest to speak only about the Other World (or Other Worlds) and fairies.

It is obvious, however, that beside the old belief there might have been also other motives which might have influenced the conception of the Other World and of fairies; I mean especially ethnical motives: an alien race and a distant country might have been regarded as an 
Other World; the predatory expeditions of some successful chieftains against an alien country may have enriched this motive. So it is possible that the poem from B. of Tal. $25^{\text {b }}$ (Skene, ii. I 81 ) relates partially to some prehistoric expedition (cf. Skene, i. 228). The same ethnical traces some scholars see in modern fairy-lore (cf. Rhys, Celtic Folklore, but see also Hartland's Science of Fairy Tales, pp. $349 \mathrm{ff}$.). Similar traces of peoples who dwelt in some subterranean locality are suggested by Popol Vuh.

We see that the conception of the Other World is a complex one, that it results from various motives, and I do not suppose that we have any right to presuppose that in the earliest times this conception was much simpler. The Insular Celts, as they came to the British Isles, had already absorbed many foreign elements, and assimilating the older population of the British Isles they underwent further modifications; we can hardly expect that the different stages of culture through which they had to pass should not have left traces in Insular Celtic religious conceptions, coexisting with others which were quite contradictory to these. In many religions we find different strata and different or contradictory ideas one beside the other, the best example of this being found in the old Egyptian religion. One might, however, object that the analogy of Egyptian religion does not prove anything for the old Celtic, and I must agree with this; but there are certain facts in folklore survivals which prove that in Britain two contradictory ideas existed. Sir Laurence Gomme has proved that there existed two different attitudes towards the deceased, one of which was based on fear of the dead, and another reflecting love towards the deceased (Ethnology in Folklore, pp. 109 ff. and especially 125 ff.). I will not argue that these different survivals presuppose different races. I think it possible that these new influences may be of other kinds beyond the racial admixture : this question is, however, the old crux of archaeology, being identical with 
the question: "Does a new culture presuppose a new race?" There is, however, another difficulty in Sir Laurence Gomme's deductions. He thinks the IndoEuropean creed was a clearly developed system; but there are so many difficulties in the reconstruction of this old creed, seeing that we know nearly as little about Indo-European beliefs as we know about the creed of the pre-Celtic inhabitants, that we come to the conclusion there is little definitely proved about either. Hence there remains nothing but to remember the often-quoted words (Caesar, De bello Gallico, vi. 18. I): Galli se omnes ab Dite patre prognatos praedicant, idque ab Druidibus proditum dicunt..., which would again point in favour of ancestral elements in Celtic religion. From this "Other World" some bold or chosen mortal can get precious gifts or immense booty. That this "Other World" is not represented always in the same manner is a known fact (vide M'Culloch, Rel. of Anc. Celts, pp. $362 \mathrm{ff}$ ). In our case it has an actual existence in Britain, but there are in Welsh also other conceptions of this region, eg. as a distant island (see Skene, ii. 153).

Finally, it must be remembered that Arawn had some wonderful dogs, "and of all the hounds that he (i.e. Pwyll) had seen in the world he had never seen any that were like unto these. For their hair was of a brilliant shining white, and their ears were red; and as the whiteness of their bodies shone, so did the redness of their ears glisten" (R.B. fo. 7 10/I1, W.B. fo. $17 \mathrm{I}$ a-b : Ac or a welsei ef o helgwn y byt, ny welsei cwn un lliw ac wy'nt. Sef lliwo oed arnunt: claerwynn llathreit ac ell clusteu y" gochyon. Ac val $y$ llathrei wynnet $y$ cwn y llathrei cochet $y$ clusteu). These hounds are the cwn Annwn of the Modern Welsh folklore

- There is often a taboo not to eat any of the food of the Other World: whoso partakes of it cannot retum to this world (Hartland, Science of Frairy Tales, pp. 37 sgg.), but in the Pwyll story we do not find any trace of such a taboo. 
(vide Miss Marie Trevelyan, Folk-lore and Folk-stories of Wales, pp. 47-54), which are regarded as an omen of death, a fact which speaks in favour of our conception of Annwn. It may, of course, be objected that this modern belief may be a later development of the folk-belief, but we must acknowledge, on the other side, that the idea of Death as Hunter (cf. our hunting scene in Mabinogi) is a very old and very common one; and so it is quite clear that the King of $A$ nnwwn is represented as a king of the country of Death. But this region was not always described as a beautiful and desirable country (eg. Procopius, De bello Gothico, iv. 20. 24), but as the belief was never homogeneous, death appeared sometimes as a horrible demon and sometimes as a good man (so e.g. in the tales, Death as a Godfather):

Pwyll is probably an ancestor of some Dyved (Demetae) tribe, but he is at the same time in a very close connection with the Under World, so we find in old Welsh poems (Skene, ii. 181; Book of Taliesin, 25 b) :

Bu kyzweir Karchar Gweir yg Kaer Sidi

Trwoy ebostol Preyll a Phryderi;

and (Skene, ii. 155):

Ys kyweir oyg Kadeir yg Kaer Sidi

Is gzoyr Manawiont a Phryderi,

which makes it probable that Pwyll is a supernatural being, penn Annzyn, chief of the Under World, and the tale is told to account for this title and to explain how Pwyll penndevic Dyvet was at the same time penn Annwon.

[The name Pwyll means "sense" (Irish ctall). Such a name as an ancestor-name is not unique. The indigenous Bohemian kings derived their origin from a mythic ancestor (ploughman), Premysl, which means a "thoughtful one."]

\footnotetext{
- Brown, Harvard Studies, vili. 48/7, suggests that Arawn is here ased instead of Manawyddan (Ir. Nananndn); about this suggestion vide infro.
} 


\section{The Second Part of this Branch.}

The second part of this branch of the Mabinogi deals with Pwyll and Rhiannon, and it contains again three leading motives.

(a) Pwyll and Gwawl;

$(\beta)$ Rhiannon punished for her supposed killing of her own child; and

(y) "Stolen child."

(a) The first motive was originally an independent Mälurchen ; that the application of this Mährchen to Pwyll and Gwawl was pretty current is proved by the repeated mention of enmities between Preyll's son Pryderi and Llwyd vab Cil Coet, who endeavours to avenge his friend Gwawl on Pryderi and Rhiannon; even the grware broch yg $\cot$ (R.B. 750, W.B. 170 a) is mentioned.

The name of Rhiannon is identical with the name of the Old Celtic Rigantona (name of goddess), but I do not know whether we are right in supposing that our Rhiannon. is an ancient goddess; what we know of her from Mabinogi allows only one conclusion; it is that she is a lady of great magical knowledge, and in this point she does not differ from Gwydyon, about whom the Old Welsh poem says (R.B.; Skene, ii. 302):

$$
\begin{aligned}
& \text { New Lew a Guydyon } \\
& \text { a vuant gelvydyon. } \\
& \text { new a wdant lyfyryon. } \\
& \text { "Or Lleu and Gwydyon } \\
& \text { were they creators (or skilful producers), } \\
& \text { or did they know books?" }
\end{aligned}
$$

This suggests that these mythical personages were merely great magicians, or that even if they possessed a divine power, this power resulted merely from their knowledge of magic.

As to the tale itself, Miss Lucy Paton (Studies in the Fairy Mythology of Arthurian Romance, p. 225 n. 5) com- 
pares the entrapping of Gwawl with an incident from Parcival's career: a knight asked Parcival to rescue him from a tomb, which done, the ungrateful knight imprisoned Parcival himself in the tomb. This incident is, however, to be compared rather with a trick of the Irish Naked Hangman (vide Ériu, vii. 20I). The magic bag, however, is well known from other stories, e.s. that of The Three Gifts. One of those gifts is a magical bag, and the hero imprisoned therein is a devil or Death. The imprisoned devil gets a sound hammering (cf. gware broch).

Prof. A. C. L. Brown (Harvard Studies, viii. 49) thinks that the original idea of this tale is similar to that of Iwain, " the idea of representing the fee as guarded by a suitor or husband who must be overthrown before she can be approached might naturally be developed." I am a priori disinclined to presuppose such very wide formulas for cycles containing such divergent motives. This method ignores, further, the fact that our stories are mostly compilations of different tales, and finally it must not be forgotten that two stories with some similar or identical motives do not necessarily presuppose the same original story.

The formula how Gwawl deceived Pwyll reminds us of Étán's story: Mider won a game against Eochaid and named Eochaid's wife as the stake, and Eochaid was to give him Étáin.

As for the tabooed hill (Gorsedd), vide MacInnes, Folk and Hero Tales, p. 456 (note to p. 97).

$(\beta)$ and $(\gamma)$ It will be better to take the $(\gamma)$ motive first. Pryderi is stolen by a mysterious hand. This motive is very frequent in Irish and Scotch Gaelic, and has two distinct variants :

(a) Either the child is saved by a werwolf (cf. Scottis/s Celtic Review, i. (Tuairsgeul morr), note by A. Nutt, p. 140; Kittredge, Harvard University Studies in. Phil. and Lit. viii. 227). 
(b) Or the rescuer is a hero (Finn in MacInnes, p. $62 \mathrm{f}$; J. M'Dougall, Folk and Hero Tales, pp. 2 ff.; vide Kittredge, op. cit. 223).

[Cf. A.S. Beowulf, but his name suggests a person with werwolf attributes. Cf. Kittredge, l.c. 227.]

(a) The motive of the kidnapped infant is sometimes entangled in the Amor and Psyche (Beauty and the Beast) Cycle (Mod. Ir. in C.Z. i. 176 f.; ; Gaelic, M'Dougall, Folk Tales and Fairy Lore, p. 2 ff.). Soon after the Beast's wife has borne a child a mysterious hand steals the infant. Sometimes the incident of dropping or tearing away the hand does not occur. [A Scotch story seems to identify the Mysterious Hand with the Beauty's Husband (cf. also Kittredge, op. cit. 24i, n. 4).]

$(\beta)$ There is, however, another kidnapping motive; the tale where it occurs is pretty common in the whole of Europe. A maiden breaks the taboo not to enter a (tabooed) room; in consequence of her disobedience she is banished (and usually deprived of speech); a prince finds her and marries her, but whenever the young princess gives birth to a child, the being (whom she has offended by breaking the taboo) comes and steals the child away. The mother is accused of cannibalism and sentenced to death.

Sometimes the thief of the children throws the suspicion of cannibalism directly on the mother by smearing her mouth with blood. A similar incident is found in the Abandoned Wife (Genofefa) Cycle, where the wife is blackmailed by the mother-in-law or by her jealous sisters (see Kittredge lc. 24 I f.).

. Now we find in the Mabinogi story a real Mysterious Hand motive, but we find also incidents which apparently belong to the other above-mentioned cycles, viz. ( 1 ) measures are taken to throw on Rhiannon a suspicion of cannibalism, (2) the mother is punished.

It is to be noticed that in tales where the Mysterious Hand steals the infant the mother is not suspected of any heinous 
crime. In cases where it is entangled in the Amor and Psyche motive the wife has to suffer from the jealousy of the other woman, and so we might think that it was also here a jealousy or hatred which brought Rhiannon into this evil plight. But, unfortunately, we have no proofs of it ; it is just here that our story differs from those mentioned under $(\beta)$. The attendants accuse Rhiannon of cannibalism merely to avoid the punishment for their carelessness; and so we can only say that two different cycles have been combined. It seems that there have been mixed up both cycles mentioned under $(\beta)$; the fact that the child was stolen in the Taboo-Breaker Cycle may have contributed to overlapping in this direction. There is, however, one incident which points to the Abandoned Wife Cycle, viz. the lord's demand of Pwyll to put away his wife because of the heinous crime which she has committed (R.B. 723, W.B. fo. I78 a-b, $A r$ gwyrda a doethant y gyt y wneuthur cennadeu at Pwyll y erchi idaw yscar ae wreic an gyflavan mor anzwedus a rywnaethoed). Pwyll declined this request; now just such repudiation was the fate of the Abandoned Wife, and so we are probably right in supposing that this cycle also has influenced our tale.

- As for Rhiannon's punishment,' she has to sit at the outer gate of the court and to tell her story to every comer and to offer to carry him to the court, i.e. she is degraded to a mule. We find another such incident in her life: when she was imprisoned in the enchanted castle (Branch : Manawydan vab Llyr), she had the collars of the asses, after they have been carrying hay, about her neck (R.B. 75I,

'Cf. Kittredge, Harvard University Studies and Notes, vili. p. 242 ff.

- But cf. the Abandoned Wife's punishment in Dolopathos (Oesterley, 75): "I peam vero, nulla sibi pro se respondendi aut megandi crimen facullate concessa, virnm in medio palatii sul infodi usque ad mamilles inbet, precipiens omnibus militibus, servlentibus, scurris et paresitis ut pransuri aut cenaturi manus super uxoris caput abluesent abstergerentque capillis, nullusque ef alius ad reficiendum daretur cibus quam qui canibus parabatur. Mlawsit autem sab hac iviuria sopsew continuos annos." 
W.B. fo. 191 a, $A$ Rhinnnon a vydei a mynzeireu yr essynn wedy bydyn(t) yn kywein gweir am y mynwgyl hitheu); that is again a degradation to a mule. These two incidents relating to the same fact are probably two different ways of explaining some aspect of Rhiannon's character, about which we cannot say anything more.?

There are, however, two situations belonging to another quite different cycle, viz. (a) Pwyll's men were complaining of Rhiannon's barrenness. Pwyll asked a respite of one year, and at the end of this time 'Rhiannon was delivered of a son. ( $\beta$ ) Gwri Wallt Euryn (= Pryderi) was given the horse born on the night the child was found.

According to the first passage we should expect that Rhiannon was barren, and that this barrenness was in some way removed. Stories of removed barrenness are very frequent in fairy lore. Sometimes the childless parents get a remedy from a mysterious being, but they are to give up the firstborn (son), who, after having been given to the demon, breaks the shrine-taboo (vide M'Culloch, Childhood of Fiction, 410-415). One might therefore suppose that Rhiannon was barren, and that the being who gave her the remedy was identical with the owner of the Mysterious Hand, but this combination does not, after all, appear quite probable, because there is a fact which speaks strongly against this point of view, i.e. the Hand takes every born (not only the firstborn) creature. Or is this a dim relic of some form of old belief?

The second incident is frequent in the Supernatural Birth stories : the wife is given a meal, of which also some house animals partake; the wife then has a child, the bitch has a puppy, and the mare a foal; the wonderchild and the animals are a continuation (or rebirth) of the being incarnated in the meal (and so the animals become his brothers). ${ }^{10}$.

- Was it, perhapa, to explain some such name as the Gaulish Esona?

10 Vide E. S. Hartland, The Legend of Porsews, pp. $24 \mathrm{ff}$. 
In Ireland Supernatural Birth stories are very frequent; usually a girl swallows a small animal, .which is then reborn as the respective hero or heroine (Conchobar, Conall Cernach, Cúchulainn, Étáin). In the story about Cúchulainn's conception we find, however, the version that in a certain mysterious house a child was born on the same night as two foals. Dechtire adopted the. boy, and the foals were given to him (I.T. 1. $13^{8}$ dobert som na lirchuiriz do macsiabri don macc). The boy died, however, very soon, but he was reborn to Dechtire as Cúchulainn, the incarnation of Lug (I.T. I. 139). This rebirth of the foster-son is only a doublet of the first event, and we are right in assuming that the Compert Conculaind in L.U. is a contamination of two similar stories. According to one story Cúchulainn had a horse, or two. horses, which were of the same origin as himself (I think that these horses are identical with Cúchulainn's horses, which are really represented as supernatural beings); according to another story there was no mention of the horses, and so there were tales "how Cúchulainn got his horses." These supernatural birth stories, as represented in Irish, seem sometimes to make a comptomise, according to which the child has a nominal human father (whose name the child bears), but the real father is the higher being whose incarnation the child is. These ideas of conception presuppose a very primitive civilisation, such as we find to-day among the Arunta people of central Australia, according to whose ideas the conception is due to an ancestral spirit entering into the woman; when the child is born he is a reincarnation of that ancestral spirit.

Both the last-mentioned motives, especially the last; occur in Mabinogi in a very strange context, and we do not see the reason why they have been introduced. One might, of course, suppose that there was a story of a taboobreaking woman, and that this story sometimes continued the story of removed barrenness; the taboo-breaking woman being bereft of her child. There was here, a possibility of 
50

\section{Mabinogion.}

confusion with tales having the Mysterious Hand as the leading motive. This confusion would in our case result in the following way: The Mysterious Hand remained as the leading motive, but there were introduced important motives from other cycles: the smearing of Rhiannon's face with blood and the accusation of cannibalism (her proposed punishment, cf. Abandoned Wife) and the introduction (cf. Removed Barrenness) contributed only some inorganic details. But are we justified in such a theory? We have, no doubt, good reasons to believe that there were in Wales cycles of the Mysterious Hand, Abandoned Wife, etc., but we have no proof that the motive of the female taboo-breaker was.introduced by the motive of removed barrenness.

Now, there is another possibility, ise that at least some of these stories were applied to Rhiannon, and that the compiler of Mabinogi knew different stories about one and the same event (in one case the birth of Pryderi), and that he aimed at reconciling the different versions by combining one with another. It seems to me highly probable that the story of the imputed cannibalism was introduced to explain why Rhiannon was once degraded to a mule or donkey. Is it impossible that there existed still another. tale about Pryderi's birth? It would presuppose that either Pwyll was not the real father of Pryderi, the latter being a reincarnation of some "divinity" (or rather some equivalent of Ir. stde), or that this divinity was Pwyll himself (and that Pryderi had another human father, and the name of .this mortal father in later times gave way to that of the "divine" father, both personalities having been confused). Or, finally, there may have been different tales about Pryderi's birth and different tales about Pwyll, according to which the whole character of the various persons was differently represented. Now it is possible that Pryderi himself was in older tales represented as an incarnation of some.spirit, for this would account.for the fact that Pryderi" 
is in Old Welsh poems brought in close relation with Annwvn. To explain such an incarnation a story of removed barrenness or rather some such incident as that found in Compert Conculaind might have been invented. Beside such a story there existed another pedigree explaining Pryderi's birth in some more natural way, and this tradition naturally prevailed in later times. I give here this possibility as a presumption which seems to me a most probable one, but I am quite well aware that it is only a suggestion; if I am, however, not right it must be at least acknowledged that two motives relating to Removed Barrenness and Supernatural Birth have been introduced into Rhiannon's story.

Pryderi's name is in Mabinogi explained as derived from pryder "angor," and the motive of the Abandoned (Calumniated) Wife may have been possibly introduced to explain why such a name was given to Pwyll's son. This cannot be, however, an original form of the story, because all such etiological stories presuppose the name. The original meaning of the name does not seem to me to be that of "angor"; anyhow, it is a derivative from the root "art... which appears in Ir. cruth, Cy. pryd, "form, aspect," and in the Old Welsh name of Britain, Prydain, and the Ir. name of the Picts, Cruithne. Now the name of the British heros eponymos 11 Prydain is obviously invented to explain the name of the country. But this personage is unknown in old sagas, and so it seems possible that Pryderi is the original heros eponymos of the race which gave the name to the island.

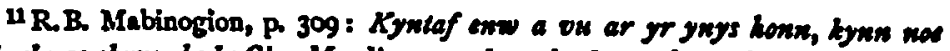

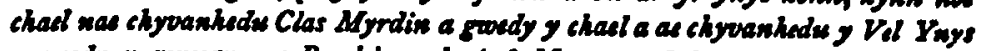

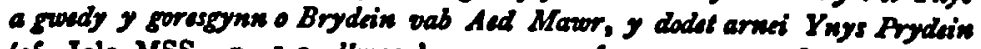
(cf. Iolo MSS., p. I-2, Lyma 'r cenwas a fu ar yr yoys how : cyn mo'i chyfaneddu, sef Clas Merddin, a chwedi dyfod o rai Cymry idali y galwid hi'r. Fal ynys... phan wybn Aedd Mawor (lege Prydain) am hynny a thegud

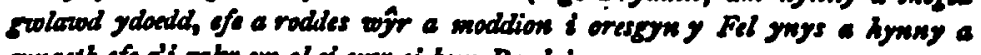
wnacth gfe a'i gatw ym ol ci enw ai hem Prydain. 
On the other hand, according to old poems, Pryderi is in close relation to the Underworld (eg. Skene, ii. 155 , 18I), and this fact would again agree with Caesar's words : Galli se ommes a Dite patre prognatos praedicant. It seems to me that the Gauls derived their origin from the Otherworld (the person of the Otherworld's king differed probably in various districts), but we cannot conclude that the Celtic "Dispater" or any other divinity was a god in the Roman or classical sense.

\section{Greri Wallt Euryn and Mabon vap Modron.}

Pryderi's original name was Gwri Wallt Euryn; now Mr. W. J. Gruffydd (R.C. xxxiii. pp. 452 ff.) has attempted to prove that Gwri is identical with Mabon vap Modron (but Gwri and Pryderi were-according to his theorytwo different persons), and later (The Transactions of the Honourable Society of Cymmrodorion, Session 1912-13, pp. $65 \mathrm{ft}$ ) he would see in the first branch of Mabinogion a transformation of a Gaelic story identical with that of Mongán.

. We will discuss the first theory first: Pryderi, according to Mr. Gruffydd, has sometimes taken the role of Gwri; now Mr. Gruffydd argues that Pryderi's imprisonment (in Mab. Manawyddan) is identical with that of Mabon. This imprisonment was, however, quite another matter, because Pryderi (or, as Mr. Gruffydd thinks, Gwri) was imprisoned in his later years and Mabon was stolen as an infant, and. since that time nobody heard anything of him (cf. W.B. fol. 28 I c, Mabon mab Modron a ducpwyt yn teimossic y wrth y vam, ny wys py tu y mae na pheth yw ae byw ae marw), and so we must suppose that he was imprisoned during some centuries; further, he was imprisoned in a horrible prison (he says, R.B. fol. 836: Oia wr, yssit le idaw y grwynaw y neb yssyd yma... ac ny charcharwyt neb kyndosted g"l llwew carchar a mi na charchar Llud Llaw Ereint new garchar Greit mab Eri). The themes of stealing the child 
(i.e. The Mysterious Hand, etc.) and the imprisonment motive arise (thus, as we find them in Mabinogi) out of two independent motives, and they occur in two different stories. According to the investigations of Sir E. Anwyl they are of different local origin. The imprisonment motive, as it occurs in the third branch of the Mabinogi, goes back to the following formula: the hero is brought to a magical castle, he touches a thing which he ought not to, and he is imprisoned. This motive occurs very often in the Quest of the Water of Life or the Magic Bird. We know from the folk-tales that it is forbidden to take anything from the land of the fairies (unless, of course, the land is conquered). From the Irish stories we know of magical castles where people are imprisoned by merely sitting down there, as in Bruidhen Chaorthainn. And so we must conclude that Pryderi's imprisonment belongs to this motive.18 But this cannot be proved of Mabon. It might be, however, probable of Gweir, because we read in the Book of Taliessin (Skene, ii. I8I):

Bu kyweir karchar Gweir yg Kaer Sidi

Truey ebostol Preyll a Phryderi

Yr gadweyn tromlas kywirwas ae ketwi

$A$ racpreidew Annwoyn tost yt geni.

Here Pryderi seems to be the Lord of Annwn, and Gweir was probably captured while trying to get some of the Underworld jewels, as he is represented bound in heavy chains before the spoils of the Underworld. This Caer Sidi

"The Mabinogi Manawydas vab Llyr is a contamination of three different cycles:

Cycle I. bas the following motives I ( 1 ) Devastation of Dyved and Mystic Fog, (2) Watching the Field ("the first two fail and are probably imprisoned (R); the third succeeds and rescues the first two).

Cycle II. (1) Hunting 3 Mystic Fog and coming to the Magic Castle, (2) tabooed objects which are not to be tonched, resulting in Imprisonment of the taboo-breaker.

Cycie III. Manarydden as an excellent creftsman in Lloegr. 
has already been identified by the late Sir E. Anwyl (Z.C. ii. 130) with the magic castle where Pryderi was imprisoned, but I do not suppose that we must necessarily identify these two places, because there were different local Otherworlds ; ${ }^{18}$ it seems, however, to me most certain that Gweir's imprisonment was something of the same kind as Pryderi's. Can we now presuppose something of the same kind about Mabon? I think not: we know of him that he was stolen from his mother, and after this time nothing was known of him till he was found in a horrible prison. This prison was in Caer Loyw (R.B. 836), and this tale might be consequently (but not necessarily) localised in Caer Loyw. Now, according to Sir E. Anwyl (C.Z. iii. 127) Gwri Wallt Euryn was a local hero of Gloucester, and so one could only suppose that both tales (that of Mabon and that of Gwri) have risen in the same locality; but if we accept the identity of Gwri and Mabon, we have to presume that the story told about Pryderi was originally told about Gwri, ${ }^{14}$ and we must accept then that both the birth and the imprisonment story related originally to Gwri Wallt Euryn, and what would remain then for Pryderi ? Nothing at all, And yet Mr. Gruffydd postulates that Pryderi was originally a son of an immortal being who took possession of him [third night]. But in this case the kidnapping of the infant would be quite otherwise represented than the rape of Mabon (and of course that of Pryderi). These theories are simply contradictory, and consequently one of them at least is wrong, and, anticipating the later arguments, I may say that the identification with Mongán's story is not only improbable, but it is, from the point of view of method, hopelessly wild. But to return to the first part of this theory: the greater part is hypothetical; neither do we

"See also Sir E. Anwyl, Celtic Religion, p. 62.

16 In farour of this point of view we draw attention to the fact that Pryderi is not likely to be a prisoner in an Otherworld, being in old poems represented 28 its king. 
know how Pryderi comes into this story if all about him refers to Gwri Wallt Euryn. Further, Mr. Gruffydd has not taken account of the results of Sir E. Anwyl's work, where he has proved that in the Mabinogi different local traditions have been contaminated. Owing to this compilatory character of the Mabinogi, we must be very careful in identifying different persons, and, what is more, in reconstructing their original story, because there is always the possibility that one motive belonged originally to one person and the other to another. Now Sir E. Anwyl has made it probable that, in some parts of Dyved, Pwyll was considered as father to Pryderi, but in the districts near Gwent, Teymon (O. Gaulish Tigernonos) passed for his father, and that Gwri Wallt Euryn belongs to the Gloucester tradition; this proves clearly enough that there have been fused together traditions of different local origin. May we now say that these persons were of similar character, and that they were therefore confused? This is, of course, possible, but we can hardly presuppose that the original stories of these persons were the same. We have shown that in the Mabinogi of Pwyll heterogeneous cycles of motives have been confused. Now it remains to be decided when these motives came to be applied to the persons in question. Without further proof we cannot argue that all the respective motives were already associated in pagan times, for example, with Pryderi or Rhiannon. The motives reflect only the old pagan belief in charms, in the Otherworld, and in supernatural beings who stole living creatures, but that is all. Some of these stories may be very old, in so far as they agree with the old poems, though even these may not represent the remotest antiquity.

\section{E. The Origins of the Mabinogi Tales.}

There is, however, still another problem as to whether these motives are native or whether they are not due to a foreign influence. This would naturally be an Irish 
influence. Mr. Gruffydd endeavours to prove that Pryderi's birth-story is identical with.the Irish story of Mongán, and he is inclined to regard the Mabinogi as of Gaelic origin. If what he tries to prove were true, then his theory would be very well founded, but I am afraid it is not true.

Mongán's story is as follows: Manannán agrees to fight for the King Fiachna on the condition that he shall be allowed to sleep in his (Fiachna's) shape with the King's wife. This done, he actually does fight for him. Manannán's son is Mongán, and Manannán carries him off when he is three days old. There are here similar motives:

(i) Exchange of shapes.

(ii) Fighting in the other's stead.

(iii) The carrying off of the child.

But these motives are either not quite identical or they are differently arranged, and, moreover, it is of great importance that we have in Irish much closer parallels to single motives in the Mabinogi than those which Mr. Gruffydd uses. To get an archetype identical with the Irish story of Mongann, Mr. Gruffydd postulates that in the original story Pwyll was a supernatural being and Arawn a human one; he thinks that only an "Immortal" can help the "Mortal," and he finds support for this suggestion in the account of the combat at the ford (R.B. 713, W.B. fo. $172 \mathrm{c}$ ), where Pwyll is alluded to as "the man who was in Arawn's place" (y gror a oed yn lle Arawn). Mr. Gruffydd argues that this passage speaks about Pwyll as a mysterious stranger. But these words do not convey any other idea than that it was not Arawn himself. Now, there are really instances which prove that a man can give help to an "Immortal":

(a) Cuchulinn is asked to help the side. The people of the fiana often help the side. The fairies require the help of a man in playing ball against other fairies. 
(b) Human heroes being able to destroy the stde, 15 a human being is consequently able to give aid to the Otherworld.

(c) [The man can help the gods or fairies in other ways. Gods really need the offerings of the people, and so do also the fairies who are, according to Irish folk-lore, entitled to spilled milk. The fairies are grateful when a hero aids their child (so, for example, in South Slav. Prince Marco and a Fairy).

And, finally, the limits between the Human and the Superhuman are never strictly defined to the primitive imagination. Superhuman beings are only superior to men through their higher knowledge of magic, and if any mortal can acquire this knowledge he can rise to the same rank as the "immortals" A man can be immortal so long as he has the water of life, or so long as his soul is hidden (vide the Egyptian tale of Anpu and Bata, Flinders Petrie, Egyptian Tales, ii. $36 \mathrm{ff}$.). The gods are jealous of their superior knowledge, so e.g. Toth felt very much offended when Ahura had got his magical book (Flinders Petrie, ibid. $89 \mathrm{ff}$.). Jehovah was afraid that man would be as one of the gods if he partook of the fatal fruits.] All these instances show that Mr. Gruffydd's presumption is not proved at all.

The motive of Pwyll's chaste intercourse is naturally, according to Mr. Gruffydd's theory, a later alteration, due to the later redactors who were shocked that Pwyll should have a real intercourse with. Arawn's wife. But why did not the redactors suppress all the "very shocking" scenes

"So the Connacht people destroyed the sed of Crwachas (see Echitra Nerai). In British folklore we have some similar instances, as Child Roland. 
of the fourth Branch of the Mabinogi, where Gwydyon and Gilwaethwy pay very scandalous attention to Goewin, and where Arianrod is represented like an adventuress in a French love-story? I do not think that the redactors were so scrupulous as Mr. Gruffydd would have us believe. Of course, Arawn did expect that Pryderi would be less abstinent than he was, but this feature is not isolated in folklore. We know that Siegfrid was also not supposed to pay merely platonic attentions to Brunhild, and for this calumny he had to pay dearly. In the Twin Brothers' story the same motive occurs. There can, of course, be no doubt that there had existed another shape-shifting motive in which the man (or woman) takes another shape to get access to the object of his admiration. So Arthur's father, Uther Penn Dragon (through Merlin's aid) came in the Duke of Din-dagwl's shape to the Duchess of Din-dagwl.10 The story of Mongan belongs, of course, to the same group. It is, however, of importance that Mongan belongs to the Christian era, and so we must presuppose that some older tradition was applied to him. (We have many instances of the exchange of one person for another, so e.g. a story told in north Ireland (Donegal) about Cúchulainn is told in the south about Fionn mac Cumhail.) It is further to be noticed that Alexander the Great's birth story also has many motives similar to those of the Irish tale, so eg. both Olympias and Philip are told that a supernatural being wishes to enter into union with Olympias, and Philip, on another day, is satisfied to hear from the expounder of dreams that the child to whom his wife Olympias is about to give birth is the son of the god Ammon. The fact that such a story existed, both in Wales and Ireland, does not, however, prove that the Mabinogi of Pwyll must be originally of the same kind; against this point of view

2 Cf. further : Signy, Wolsung's daughter, wishing to have a son of entire Wolsung's blood, exchanged her shape with some magician, and slept in ber shape with her own brother, Sigmund (Volsunga saga). 
we must put the fact that we have more than one instance of this other motive, and so we must acknowledge that the first part of the Mabinogi of Pwyll, as it is, represents a Mährchen for itself.

It may, however, be objected that I myself have presupposed a Supernatural Birth story for the second part, but I said only that some supernatural birth story has affected this second part of the first branch of the Mabinogi ; whether this supernatural birth was really analogous to the Mongan story we cannot tell. We cannot, of course, exclude the possibility that Pryderi himself may have had, according to some local tradition, a supernatural origin, but we cannot tell of what kind it was; the motives which point to Pryderi's supernatural birth occur always in stories different from the Mongan type (o.g. the wife takes some magical remedy, or she swallows the incarnation of some supernatural being).

Mr. Gruffydd finally identifies the kidnapping of the young Pryderi with the carrying off of Mongán by Manannán. But in the Welsh story the child is taken by a being which used to take also other beings besides children, and so the only way would be to presuppose that the Mysterious Hand motive was developed from the motive in which the supernatural father takes his son with him. Such a motive we find in some combinations of the Mysterious Hand with Amor and Psyche motives (vide supra), but this motive does not seem to be there in its right place. And so there is only the one way to explain the origin of the Mysterious Hand. The being stealing the children and young beasts is apparently of the same character and nature as other beings which demand the child from their parents for themselves-these beings play the prominent role in the Child's Sacrifice-Motives; now, some of these motives are closely connected with that of Removed Barrenness, so, e.g. in the Aitareya Brahmana: Harischandra prays to Varuna for a son, promising to offer the child as a sacrifice to the 
god, and after the child's birth he seeks to evade the promise. This seems to point to a primitive custom of sacrificing a first-born child in cases where barrenness had been removed. We know, besides, that the Irish sacrificed the firstlings of every issue, and the chief scions of every clan were offered to Cromm Cruach (R.C. xvi. 35); the church preached against the slaying of the yoke oxen and milk-cows and burning of the first-born progeny; the same custom is reflected also in the story that the Fomori required a third of children, corn and milk (Lebor Gabala). It is consequently possible that the Mysterious Hand motive may have developed out of such an old belief, the Mysterious Hand belonging - as we can gather from the Modern Gaelic stories-to a giant (Scotch Gael. famhair) who took the role of the old Fomorian. In favour of this explanation we may mention the fact that in the first branch of the Mabinogi there are really traces of the Removed Barrenness Cycle, which so often occurs in association with the Child's sacrifice. [Therefore, I cannot quite agree with Prof. Kittredge's suggestion that in the Mabinogi originally three children were stolen, the first two incidents having been suppressed in order to render the Calumniated Woman continuation feasible. This sug: gestion is unnecessary, because the Calumniated Woman is also sometimes bereft of three children, as is also the case in the female Taboo-breaker motive.] There is, however, the Grendel motive to be considered: here the monster does not steal any children, and yet he appears in the same way. We have then to accept that it was probably assumed that the first-born son, in a case of removed barrenness, was forfeited to some horrible monster closely related to the cannibals of the folk-tales (where the main objects of cannibal attacks are especially the children). In such tales the cannibals are sometimes supernatural beings; and possibly their character may have risen-at least partly-from the human sacrifices; and so we must not be 
surprised if we find that not only the first-born but every child is stolen by a giant. I make this suggestion, however, only as a possibility.

The fact that Mongan, when three nights old, was taken by his father Manannán to fairyland might reflect a similar idea : the child considered as a god's son belongs to the god (in the Removed Barrenness motive the child was also believed to be god's gift); this would, however, imply a slightly different motive, i.e. a Supernatural Birth, of which we have found some traces in the first branch of the Mabinogi; in such supernatural birth stories the child remains with the human parents, but if we admit that the child is sometimes really taken from them (not given to fosterage), we have to account for the change of such a Mongán story into one of the Mabinogi type. In the Mongán tale. we have no traces of such savage ideas (as human sacrifice), and it is most improbable that in the archetype of this tale there ever was anything of this kind; how shall we, then, explain the fact that the supposed Welsh deterioration of the Irish tale has preserved the older, more savage, feature, i.e. the monster stealing the children ? or shall we ascribe it to the "monkish redactor" who guessed our modern theories? I hardly think so.

The same difficulties appear in Mr. Gruffydd's association (ibid. pp. $20 \mathrm{ff}$.) of the tale of Llew Llawgyffes (R.B. 763 ff.; W.B. fo. 195d ff.) with Ir.: Aided Conrot, which presupposes a common origin for these two tales. If these words were to mean that this common origin goes back to a very remote period, there would be little difficulty, but Mr. Gruffydd thinks that:the Irish story is the original one, and he argues that the identities of both stories prove the Gaelic origin of the Mabinogion. But unfortunately there.are not only similarities in both tales, there are also:great divergences.

The main divergence is that the Irish tale had originally an External Soul motive (Ériu, vii. pp. $200 \mathrm{ff}$.), of which the 
Welsh story has no unmistakable traces; here the hero (Llew) is invulnerable except with a certain weapon and in a certain position. This magic weapon might be perhaps a remnant of an external soul motive: in Irish story Cúroi's sword is a necessary instrument for destroying Cúroi's soul, because it is his own sword. It would be only natural then if the slaying power of the sword were explained, not as a possession of the hero who is to be killed, but as a supernatural quality of the sword itself, and so it is possible that in this way the story-teller came to evolve the idea of a magical weapon. There is, however, still another motive which does not occur in the External Soul theme: the hero can be slain only under certain conditions; otherwise he is deathless: Llew cannot be killed either within a house or without; he cannot be slain on horseback or on foot (R.B. 705, W.B. fo. $196 \mathrm{~d}$ : Ny ellir vy llad i y mywn ty...ny ellir allan, ny ellir vy llad ar varch ny ellir ar vyn troed). The words are a formula intended to mean : he cannot be killed at all and a situation is invented which satisfies this formula. This motive that somebody is cunning enough to avoid diff. culties comprised in some regulation intended to be incapable of being performed is common enough. A lord gives an order to his peasant subject that his (i.e. the peasant's) daughter shall come to him neither riding nor going (on foot); the daughter comes walking on one foot and the other leg on the back of a goat. (It is very significant that Llew has to put one foot upon a buck.)

Another example of this motive we find in the Mahābhārata (18.43.2434): Indra made friends with Namuci, and promised not to slay him with wet nor dry, in the day nor in the night. One day Indra beheld a fog, and cut off the head of Namuci with foam of water. We see that in such stories only the negative form is given; the method of evading the formula is to be found by the opponent, and so I suppose that originally Llew himself said only the 
negative part of the formula: the situation in which he could be slain was invented either by his wife Blodeuwedd or by Gronw Pebyr. [The reason why Llew says the positive part of the formula as well may be confusion with the Separate Soul Cycle, where the giant himself says how he can be slain.]

The fabrication of the magical spear may reflect some traces of an old belief in the childhood of mankind that every new and better weapon was a magical one; metal weapons were of course regarded with great awe, and their fabrication was naturally considered as a magical performance; a trace of this creed is found in the belief that blacksmiths are cunning people who can perform magical things, ${ }^{17}$ so we find in St. Patrick's prayer, vv. 48, 54:

Toaviriur etrum ... inna huli nert so

fri brichlu ban ocus gobann ocus drwad.

"I summon all these powers between me [and these] ... against the spells of women, blacksmiths and druids."

In modern Japan the fabrication of a sword is a religious performance.

The other main difference from the Aided Conrot is the fact that Llew was not yet killed: he was only transformed into an eagle (R.B. 766, W.B. 197 ab : Ac ar gwenwyn wayze y vwrw ay vedru yn y ystlys yny neita y paladyr o honaw a thrigyaw y penn yndaw. Ac yna bwrw eletvan o honaw yntex yn rith er'r a dodi garymleis anhygar. Ac ny chahat y welet o hynny allan). There are two possibilities: either Gronw has made some mistake or Llew was really killed. Now Mabinogion does not mention any mistake, and so we should expect that Llew was really killed; if we find that he was transformed, this agrees with primitive ideas

"If. Vulcan's maidens, a smith makes a living stag, etc. (Vide Mr'Dougall, Folk-7ats, $16 \mathrm{fi}$ ). 
according to which death and life are not so strictly separated one from another as in our modern ideas: the dead man is not really dead; he could live again. This old belief is reflected in many motives, one group of which is the most important for us, i.e. the dead takes the form of an animal or a plant (M'Culloch, The Childhood of Fiction, pp. $108 \mathrm{ff}$.); this group is connected with the old belief that the dead man assumes the shape of his clan totem. In our.case the question is still simpler, as Llew is transformed into an eagle, and the soul has, according to the wide-spread belief, a bird's shape. The rest is only a logical consequence of this belief: if the dead continues living in another shape, there must exist some means to restore his original shape and he can live again. Usually the relatives and friends of the dead know what to do, and this of course is known also to Gwydyon, who in this episode plays the role of the relative, for he strikes Llew with his magic wand to restore his form (R.B. 768, Ac ynay trewis Groydyon a hutlath ynteu yny vyd yn y rith o hunan). This results from Gwydyon's general magic nature (cf. Skene, ii. 302, Neu Lew a Gwydyon a vuant gelvydyon | neu a wdant lyvyryon "Or Llew and Gwydyon were they. creators (artists), or did they know books?") So in a Basuto tale: a girl is devoured but her heart escapes as a bird, and when the wings are pulled off the girl assumes again her own shape. We might define this belief as follows : the dead gets only another hamr (skin), and it is his rescuer's task to get this hamir off.

- It is worth while considering the tales in which this motive occurs ; it is either the dead mother who takes the şhape of some animal (Cinderella motive) or a slain person seeks his revenge on his murderers (jealous sisters or cruel stepmother), or, finally, a womän is transformed by another woman who seeks to take her place. This motive is farely, connected. with the motive of the Treacherous. Wife, and yet we have a very old instance of this. combination, 
viz. the Egyptian story of Anpu and Bata (Flinders Petrie, Egyptian Tales, ii. pp. 49 ff.) : Bata took his heart (i.e. soul) out of his body and hid it in the flowers of an acacia tree. He told his brother Anpu that his (Bata's) death would be revealed to him by a "life token," and if this happened Anpu must come and search for his soul. They now took leave of each 'other, and Bata lived in the valley of the acacia. Once he met the Nine Gods, "and Ra Harakti said to Khnumu: 'Behold, frame thou a woman for Bata that he may not remain alive alone.' And Khnumu made for him a mate to dwell with him. She was more beautiful in her limbs than any woman who is in this land. The essence of every god was in her. The seven Hathors came to see her: they said with one mouth, 'She will die a sharp death." "Bata lived happily with his wife, and told her of the secret of his life. A lock of her hair was carried down the river and taken to the Pharaoh, who bade to be made a search for its owner. ${ }^{18}$ When found, she became Pharaoh's wife, and desired the acacia tree to be cut down. This done, Bata died, but his brother found his heart and restored it to the dead, and Bata "became as he had been." After this Bata transformed himself into an Apis bull, which his unfaithful wife caused to be killed. Two drops of the blood fell on either side of the door, and from them grew up two persea trees; she ordered them to be cut down, but a splinter flew into her mouth, and Bata was in due time reborn as Pharaoh's son, and as he became the king his mother (i.e. Bata's treacherous wife) was brought before him, "and he judged with her before him, and they agreed with him" (i.e. probably she met "a sharp death"). Professor Flinders Petrie remarks of this story:" "The

${ }^{13} \mathrm{Cf}$. Iwolda's hair is brought to King Marc, and he desires to marry the owner of this hair.

"M'Culloch (The Rel. of Anc. Celts, 108) has already obeerved the Identity of Llew's tale with the Egyptian. But he did not compare both stories sccording to his opinion there is no "Separable Sonl" motivo (but see his Childhood of Fiction, p. 142 f.). 
sudden death of Bata so soon as the depository of his soul was destroyed is a usual feature in such tales about souls. But it is only in the Indian tale quoted by Mr. Frazer that there is any revival of the dead, and in no case is there any transformation like that of Bata." Now in our Welsh tale we have an instance of such a transformation, and the main frame of the story agrees more with the Egyptian version than with the Irish: in both versions the wife is made for the hero. (In the Irish version we have nothing of this kind, but the wife is kidnapped by Curroi, and has therefore good reasons to hate him ; her rescuer Cúchulainn is at first beaten.) In both tales the husband is trans. formed into an animal and takes his revenge personally on the faithless wife. (In the Irish, Curroi's soul being totally destroyed, there is no possibility of his revival.)

Professor Flinders Petrie calls this tale a "patch-work," and it really seems as if there were two different motives mixed together, i.e. the "Separable Soul" and the "Shapeshifting of the Dead." If, now, in the Welsh story the "Separable Soul" motive had once a more important role than we find in the present version, it would be an extraordinary coincidence with the Egyptian tale; if there was no such motive it is the less similar to the Irish tale, and so the theory of the Goidelic origin of this tale proves to be quite improbable. I will not deny the Gaelic influence; but this does not yet imply that most of the Mabinogi stories are of Gaelic origin. The influence of Gaelic on Welsh is surely sometimes overrated, and philological researches prove that the influence of Brythonic on Gaelic was much greater than vice versd, and we find in Irish a great number of Brythonic loanwords (see Pedersen, Vergleichende Grammatik der keltischen Sprachen, \$24). ${ }^{20}$

20 It is very important for our purpose that Cúchulainn's first name, Setanta, seems to'be of Brythonic origin (ef. Brit. Setantioi , old Setantios would give in Ir. * Ssocide, spelt * Sethaite). If this name is of Brythonic origin it must have come to Ireland after the time of lenition and assimilation $m t>d$. 
In prehistoric times there were probably some Brythonic races in Ireland, and in later Christian times there was a great influx of Welsh students into Ireland, and so we must never forget that British folklore and traditions might also have influenced the Irish.

There is, however, a possibility of quite foreign influences, and this is far more important. We can never totally exclude the possibility of some Mediterranean culture elements influencing the insular culture. Archaeology proves only that Celtic art had absorbed some Mediterranean ornaments, etc., but we know that there was a commercial contact between the Mediterranean and the isles, and by this way some motives might have come to Britain already in prehistoric times. I think that the above discussed Llew story might have had such an origin. I will not argue that the Irish story is of foreign origin, but in Welsh the curious combination of motives, which is so similar to the Egyptian, puzzles me. But this part of the Bata story is, according to Professor Flinders Petric (l.c.) of Asiatic and not of Egyptian origin.

It might be also of some interest to compare the Irish story of Étáin's kidnapping and the Pali Jataka, No. 327. The Irish story has preserved much better the original features: King Eochaid Airem lost a game (in chess) against the fairy King Mider, and Mider was entitled to name the stake, and he demanded Eochaid's wife Étảin, whom later he carried off. It is important that he eloped as a bird. In the Jataka the King of Garudas (birddemons) used to come to the King of Benares and play dice with him; he fell in love with the queen, whom he carried off. The king's poet, hidden in the Garuda-King's feathers, was carried to the palace of the queen. In the Irish story it is one of Eochaid's druids who finds Etáin.

Now in the Pali tale the dice-playing is not explained; the Irish gives a good explanation for it; but, as regards the origin of this motive, I should rather think that it is 
not Irish; it is further very significant that also the first life of Étáin "has some unique features, as it alone among Western Mährchen saga variants of the 'True Bride" describes the malicious woman as the wife of Mider. In other words, the story implies polygamy, rarely found in European Folk Tales" (M'Culloch, The Religion of Ancient Celts, p. 83, note 2). Our Jātaka story is referred to in another part of the Jātakas as an example of woman's infidelity ; Étáin is not directly described in the same way, but her conduct towards Ailill Anglonnach cannot be regarded by any means as a pattern of wifely chastity.

I am far from considering that these facts are a real proof of Oriental origin for the Étain story, but they are remarkable enough to be worth considering in connection with this possibility.

JOSEF BAUDIŚ. 